\title{
PERENCANAAN LERENG SUNGAI SUGUTAMU PADA LOKASI PROYEK PESONA SQUARE DEPOK
}

\author{
Putera Agung Maha Agung ${ }^{1}$, Ramadhanty Saputri ${ }^{2}$, Umar Alfaruqi Abdurrahman ${ }^{3}$. \\ 1,2,3 Politeknik Negeri Jakarta, Jl. Prof. Dr. G.A Siwabessy - Kampus Baru UI Depok, No. Telp 021 7270044, \\ No. Fax 0217270034 \\ Email: ${ }^{1}$ putera_agung2002@yahoo.com
}

\begin{abstract}
The location of inspection and vehicle road at Pesona Square Depok Project is on the side of Sugutamu River and contoured land giving a worried about sliding and erosion. This research was conducted for design the Slope of Sugutamu River At Pesona Square Depok Project which is effective, efficient, and gives comfort to the people there in using the road. Slope stability planning divided into 4 phase of calculation. Slope without outside load and not affected by river water surface phase, slope without outside load but affected by river water surface phase, slope with outside load but not affected by river water surface phase, and slope with outside load and affected by river water surface phase. The analysis uses two methods, manual analysis Fellenius methods and computer analysis PLAXIS program version 8.2. The shape and angle of the slope selected in this design is $60^{\circ}$ and no-staging.. The value of minimum safety number from manual calculation of Fellenius method is 1,287 and PLAXIS program version 8.2 is 3,718. The value of the safety factor used is 1.25 .
\end{abstract}

Keywords: slope stability, safety factor, Fellenius method, PLAXIS version 8.2

\begin{abstract}
ABSTRAK
Letak jalan inspeksi dan kendaraan pada Proyek Pesona Square Depok yang bersebelahan dengan Sungai Sugutamu dan bentuk tanah yang berkontur menimbulkan kekhawatiran akan terjadinya sliding dan erosi. Penelitian ini dilakukan untuk merencanakan lereng Sungai Sugutamu Pada Lokasi Proyek Pesona Square Depok yang efektif dan efisien serta memberikan kenyamanan kepada warga setempat dalam menggunakan jalan tersebut. Perencanaan stabilitas lereng dilakukan dalam empat fase perhitungan. Fase lereng dalam keadaan tanpa beban luar dan muka air sungai, fase lereng tanpa beban luar namun dipengaruhi muka air sungai, fase lereng dibebani beban luar namun tidak dipengaruhi muka air sungai, serta fase lereng dibebani beban luar dan dipengaruhi muka air sungai. Analisis menggunakan dua metode yaitu analisis manual metode Fellenius dan analisis komputer dengan program PLAXIS versi 8.2. Bentuk dan sudut kemiringan lereng yang dipilih dalam perencanaan ini yaitu sebesar $60^{\circ}$ dan tanpa undak (nostaging). Nilai angka keamanan terkecil yg didapat dari perhitungan manual metode Fellenius yaitu 1,287 dan program PLAXIS versi 8.2 sebesar 3,718. Nilai minimum faktor keamanan yang digunakan sebesar 1,25 .
\end{abstract}

Kata kunci : stabilitas lereng, faktor keamanan, metode Fellenius, PLAXIS versi 8.2

\section{PENDAHULUAN}

\section{Latar Belakang}

Sektor properti di Indonesia terus mengalami pertumbuhan setiap tahunnya. Salah satu investor yang tertarik untuk berinvestasi adalah PT. Menara Depok Asri. PT. Menara Depok Asri sebagai salah satu investor yang bergerak di bidang properti yang telah memulai pembangunan superblok “ Pesona Square Depok “ di Kota Depok, Jawa Barat. Letak Pesona Square Depok berada di jantung Kota Depok, yakni di jalan raya Ir. Juanda. Kawasan ini berada tepat di tepi Sungai Sugutamu. Lokasi proyek berkontur dan beda tinggi antara lokasi proyek dan Sungai Sugutamu antara 3-9 m. Di tepi lereng akan dibangun akses untuk kendaraan dan pejalan kaki untuk warga setempat. Oleh karena itu, proyek Pesona Square ini dapat dipastikan sangat membutuhkan struktur dinding penahan tanah yang berfungsi untuk menahan tanah agar kondisinya terus stabil dan mencegahnya dari longsor atau terlindung 
dari erosi. Penelitian ini dilakukan untuk membantu warga setempat menggunakan akses jalan tersebut secara nyaman dan aman. Penelitian dilakukan menggunakan 2 metode perhitungan, yaitu metode manual Fellenius dan program bantu Plaxis v.8.2. Atas dasar inilah diharapkan luaran dari penelitian ini dapat digunakan sebagai dasar pelaksanaan pembangunan dinding penahan tanah pada proyek Pesona Square Depok.

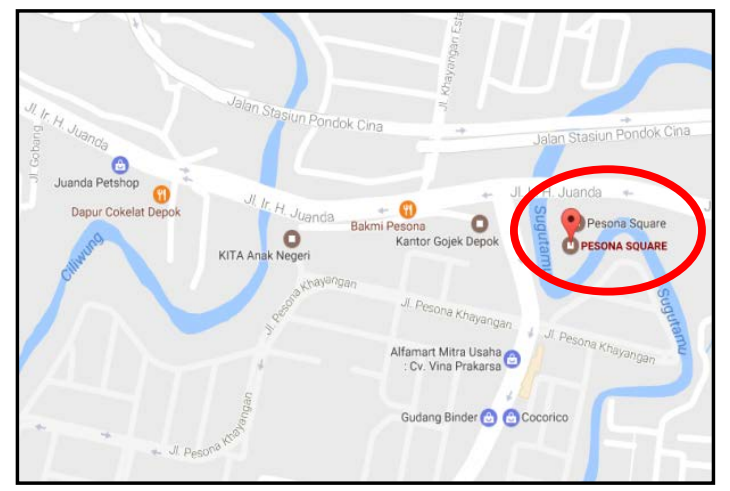

Gambar 1. Peta lokasi Proyek Pembangunan Pesona Square Depok

\section{Tujuan}

Adapun tujuan yang hendak dicapai pada penelitian ini adalah:

a. Merencanakan dinding penahan tanah pada lereng Sungai Sugutamu berdasarkan hasil dari pengolahan data SPT, sondir, dan laboratorium yang kemudian diolah menggunakan perhitungan dan juga manual program PLAXIS versi 8.2 .

b. Membandingkan hasil perhitungan stabilitas lereng yang menggunakan perhitungan manual dengan program PLAXIS versi 8.2.

c. Menganalisis hasil perbandingan hitungan stabilitas lereng yang menggunakan perhitungan manual dengan program PLAXIS versi 8.2.

d. Menghasilkan gambar rencana yang nantinya akan menjadi dasar pelaksanaan dilapangan.

\section{Tinjauan Pustaka}

Dasar teori yang menjadi dasar penelitian dalam penelitian ini adalah sebagai berikut;

a. Tanah

Tanah merupakan bahan padat (mineral atau organik) yang terletak di permukaan bumi, yang telah dan sedang serta terus mengalami perubahan yang dipengaruhi oleh beberapa faktor seperti bahan induk, iklim, organisme, topografi, dan waktu (Dokuchaev, 1899). Jenis tanah secara umum terdiri dari tiga komponen, yaitu partikel padat (solid), air serta udara. Partikel padat, air dan udara yang terkandung dalam tanah tersebut masing-masing mempunyai berat dan volume.

Jenis tanah yang sering dijumpai diantaranya adalah kerikil, pasir, lanau dan lempung. Tanah dengan butiran halus dibedakan menjadi dua yakni, lanau (silt) dan lempung (clay).

Setiap jenis tanah memiliki karakteristiknya masing-masing. Cara mengetahui karakteristik tanah (sifat fisik) dapat dilakukan melalui pengujian makro. Pengujian yang dilakukan diantaranya adalah:

1) Kadar air (water content) (w)

2) Berat jenis tanah (spesific gravity) $\left(\mathrm{G}_{\mathrm{s}}\right)$

3) Berat Isi (weight content) ( $\square$ )

4) Analisis ukuran butir (sieve analysis)

Analisa ukuran butir adalah pengujian yang dilakukan untuk mengetahui diameter butiran dan masing masing persentase ukuran partikelnya. Metode yang dilakukan dalam penenelitian ini adalah metode penyaringan (analisa saringan) dan metode hidrometer (analisis hidrometer). 
5) Atterberg Limits (LL; PL; PI)

Klasifikasi tanah dilakukan untuk memberikan gambaran sepintas mengenai sifat - sifat tanah terkait dengan analisa stabilitas lereng.

1) Klasifikasi Tanah Berdasarkan Data Sondir (Robertson \& Campanella, 1982)

2) Modulus Young (E)

3) Kohesi (c)

4) Poisson Ratio ( $\square$ )

5) Permeabilitas (k)

6) Sudut Geser Dalam $(\phi)$

b. Analisis Stabilitas Lereng

Proses menghitung dan membandingkan tegangan geser yang terbentuk sepanjang permukaan longsor yang paling mungkin dengan kekuatan geser dari tanah bersangkutan dinamakan dengan Analisis Stabilitas Lereng (Slope Stability Analysis).

Semua metode irisan menyatakan kondisi kestabilan suatu lereng dinyatakan dalam suatu indeks yang disebut faktor keamanan (FK), yang didefinisikan sebagai $\mathrm{FK}=\tau / \tau \mathrm{d}$ dengan $\tau$ adalah tahanan geser maksimum yang dapat dikerahkan oleh tanah, $\tau \mathrm{d}$ adalah tegangan geser yang terjadi akibat gaya berat tanah yang akan longsor.

Karakteristik lainnya yaitu geometri dari bidang gelinciran harus ditentukan atau diasumsikan terlebih dahulu. Untuk menyederhanakan perhitungan, bidang runtuh biasanya dianggap berbentuk sebuah busur lingkaran, gabungan busur lingkaran dengan garis lurus, atau gabungan dari beberapa segmen garis lurus.

Setelah geometri dari bidang runtuh ditentukan kemudian selanjutnya massa di atas bidang runtuh dibagi ke dalam sejumlah irisan tertentu.
Pada penelitian ini analisa stabilitas lereng menggunakan Metode Irisan Biasa (Fellenius). Asumsi yang digunakan dalam metode ini adalah resultan gaya antar irisan sama dengan nol dan bekerja sejajar dengan permukaan bidang runtuh, serta bidang runtuh berupa sebuah busur lingkaran. Kondisi kesetimbangan yang dapat dipenuhi oleh metode ini hanya kesetimbangan momen untuk semua irisan pada pusat lingkaran runtuh. Faktor keamanan didefinisikan sebagai :

$$
\mathrm{FK}=\frac{\begin{array}{c}
\text { Jumlah momen dari tahanan geser } \\
\text { pada bidang longsor }
\end{array}}{\begin{array}{c}
\text { Jumlah momen dari berat massa tanah } \\
\text { yang longsor }
\end{array}}
$$

[Pers.1]

Gempa bumi dapat mengakibatkan gerakan dan keruntuhan lereng alam maupun buatan. Akibat lain dari gempa bumi adalah adanya Liquefaction pada massa tanah, terutama pada tanah-tanah granular, adanya perubahan tekanan air pori dan tegangan efektif dalam massa tanah dan timbulnya retak-retak vertikal yang dapat mereduksi kuat geser tanah. Untuk memperhitungkan pengaruh gravitasi akibat gempa, hal yang sering dilakukan dalam analisis stabilitas lereng adalah dengan menggunakan konstanta numerik yang biasanya disebut koefisien gempa (g).

c. Peraturan Pembebanan

Peraturan yang digunakan untuk menghitung beban-beban yang ada dalam perencanaan dinding penahan tanah pada penelitian ini adalah Peraturan Pembebanan Indonesia Untuk Gedung 1983.

d. Software Analisis Stabilitas Lereng (Plaxis 8.2)

Plaxis adalah sebuah paket program yang disusun berdasarkan metode elemen hingga yang telah dikembangkan secara khusus untuk melakukan analisa deformasi dan 
stabilitas dalam bidang Geoteknik. Proses perhitungannya sendiri sepenuhnya berjalan secara otomatis dan didasarkan pada prosedur numerik.

\section{METODA PENELITIAN}

Nilai faktor keamanan dan deformasi dalam penelitian ini diperoleh dari analisis data menggunakan dua metode yaitu metode analisis manual dan metode analisis komputer. Pada metode analisis manual digunakan metode analisis Fellenius. Metode Fellenius merupakan metode yang sangat populer dalam analisis manual kestabilan lereng dikarenakan perhitungannya yang sederhana, cepat dan memberikan hasil perhitungan faktor keamanan yang cukup teliti. Pada metode analisis komputer digunakan program software analisis PLAXIS versi 8.2.

Data penelitian yang digunakan dalam penelitian ini berupa data primer yang didapat dari survey langsung ke lapangan serta wawancara lapangan dan data sekunder berupa data hasil penyelidikan tanah. Pengujian tanah dilakukan di laboratorium dengan sampel tanah berasal dari proyek pembangunan Pesona Square Depok.

\section{HASIL DAN PEMBAHASAN}

Dalam perencanaan stabilitas lereng ini, pengambilan potongan di ambil sebanyak 5 buah titik potong berdasarkan beda tinggi yang signifikan ( $\pm 1 \mathrm{~m})$. Data tanah yang digunakan dalam proses perencanaan yaitu data boring log pada titik DB III dan DB VII serta data sondir pada titik S5 dan S7. Data tersebut berasal dari hasil penyelidikan tanah Proyek Pesona Square Depok yang dilakukan oleh tim soil investigation PT Solefound Sakti beserta tim soil investigation Politeknik Negeri Jakarta. Hasil yang diperoleh dari pengolahan data tanah tersebut adalah sebagai berikut :

Tabel 1. Nilai parameter tanah pada DB III

\begin{tabular}{|c|c|c|c|c|c|c|c|}
\hline \multirow[t]{2}{*}{ Parameter } & \multirow[t]{2}{*}{ Nama } & \multirow{2}{*}{$\begin{array}{c}\text { Lapisan 1 } \\
\text { Lanau } \\
\text { Kelempungan } \\
0,00 \mathrm{~m}-1,50 \mathrm{~m}\end{array}$} & \multirow{2}{*}{$\begin{array}{c}\text { Lapisan } 2 \\
\text { Lanau } \\
\text { Kelempungan } \\
1,50 \mathrm{~m}-5,00 \mathrm{~m}\end{array}$} & \multirow{2}{*}{$\begin{array}{c}\text { Lapisan } 3 \\
\text { Lanau } \\
\text { Kepasiran } \\
5,00 \mathrm{~m}-6,00 \mathrm{~m}\end{array}$} & \multirow{2}{*}{$\begin{array}{c}\text { Lapisan } 4 \\
\text { Lanau } \\
\text { Kepasiran } \\
6,00 \mathrm{~m}-7,50 \mathrm{~m}\end{array}$} & \multirow{2}{*}{$\begin{array}{c}\text { Lapisan } 5 \\
\text { Pasir } \\
\begin{array}{c}7,50 \mathrm{~m}-8,50 \\
\mathrm{~m}\end{array}\end{array}$} & \multirow[t]{2}{*}{$\begin{array}{c}\text { Satua } \\
\text { n }\end{array}$} \\
\hline & & & & & & & \\
\hline Model Material & $\begin{array}{c}\text { Mode } \\
1\end{array}$ & $\mathrm{MC}$ & $\mathrm{MC}$ & $\mathrm{MC}$ & $\mathrm{MC}$ & - & - \\
\hline Jenis Perilaku Material & Jenis & Undrained & Undrained & Undrained & Undrained & Undrained & - \\
\hline $\begin{array}{l}\text { Berat Isi Tanah Tak } \\
\text { Jenuh }\end{array}$ & $\gamma_{\text {cans: }}$ & 15,362 & 14,571 & 15 & 15 & 14 & $\mathrm{kN} / \mathrm{m}^{3}$ \\
\hline Berat Isi Tanah Jenuh & $\gamma_{\mathrm{as}}$ & 16,479 & 15,212 & 19 & 19 & 19 & $\mathrm{kN} / \mathrm{m}^{3}$ \\
\hline Permeabilitas & $\mathrm{k}$ & $1, \mathrm{E}-10$ & $1, \mathrm{E}-10$ & $1, \mathrm{E}-09$ & $1, \mathrm{E}-09$ & $1, \mathrm{E}-09$ & $\mathrm{~m} / \mathrm{har}$ \\
\hline Modulus Young & $\mathrm{E}$ & $2500-12700$ & $2200-15000$ & $10000-25500$ & $30000-48000$ & $47000-74000$ & $\mathrm{kN} / \mathrm{m}^{2}$ \\
\hline Kohesi & c & 39 & 25 & 60 & 220 & 0 & $\mathrm{kN} / \mathrm{m}^{2}$ \\
\hline Sudut Geser Dalam & $\varnothing$ & 25 & 21,5 & 35,5 & 37,5 & 41,2 & $\ldots{ }^{\circ}$ \\
\hline Angka Poisson & $\mu$ & 0,30 & 0,30 & 0,35 & 0,35 & 0,10 & - \\
\hline Sudut Dilatansi & $\psi$ & 0 & 0 & 0 & 0 & 0 & $\ldots{ }^{\circ}$ \\
\hline
\end{tabular}


Tabel.2 Nilai parameter tanah pada DB VII

\begin{tabular}{|c|c|c|c|c|c|}
\hline \multirow{3}{*}{ Parameter } & \multirow{3}{*}{ Nama } & Lapisan 1 & Lapisan 2 & Lapisan 3 & \multirow{3}{*}{ Satuan } \\
\hline & & Lanau Kelempungan & Lanau Kelempungan & Lanaukelempungan & \\
\hline & & $0,00 \mathrm{~m}-1,50 \mathrm{~m}$ & $1,50 \mathrm{~m}-3,50 \mathrm{~m}$ & $3,50 \mathrm{~m}-6,20 \mathrm{~m}$ & \\
\hline Model Material & Model & $\mathrm{MC}$ & $\mathrm{MC}$ & $\mathrm{MC}$ & - \\
\hline Jenis Perilaku Material & Jenis & Undrained & Undrained & Undrained & - \\
\hline Berat Isi Tanah Tak Jenuh & $\gamma_{\text {vasa: }}$ & 13,667 & 15,577 & 14,398 & $\mathrm{kN} / \mathrm{m}^{3}$ \\
\hline Berat Isi Tanah Jenuh & $\gamma_{\mathrm{sat}}$ & 14,814 & 15,995 & 15,160 & $\mathrm{kN} / \mathrm{m}^{3}$ \\
\hline Permeabilitas & $\mathrm{k}$ & $1, \mathrm{E}-10$ & $1, \mathrm{E}-10$ & $1, \mathrm{E}-10$ & $\mathrm{~m} /$ hari \\
\hline Modulus Young & $\mathrm{E}$ & $2500-7700$ & $2500-11500$ & $2500-27500$ & $\mathrm{kN} / \mathrm{m}^{2}$ \\
\hline Kohesi & c & 25 & 34 & 48 & $\mathrm{kN} / \mathrm{m}^{2}$ \\
\hline Sudut Geser Dalam & $\varnothing$ & 26 & 24 & 22 & $\ldots \circ$ \\
\hline Angka Poisson & $\mu$ & 0,30 & 0,30 & 0,30 & - \\
\hline Sudut Dilatansi & $\psi$ & 0 & 0 & 0 & $\ldots{ }^{\circ}$ \\
\hline
\end{tabular}

Ada 4 fase yang akan dianalisis pada setiap potongan. Fase 1 yaitu fase lereng dalam keadaan asli, lereng tidak dibebani oleh beban jalan dan tidak dipengaruhi muka air sungai. Fase 2 yaitu lereng tidak dibebani oleh beban jalan namun dipengaruhi oleh muka air sungai. Fase 3 yaitu lereng dibebani oleh beban jalan namun tidak dipengaruhi muka air sungai. Dan yang terakhir, Fase 4 yaitu lereng dibebani oleh beban jalan dan dipengaruhi oleh muka air sungai. Potongan melintang fase perhitungan dapat dilihat pada Gambar.2 berikut

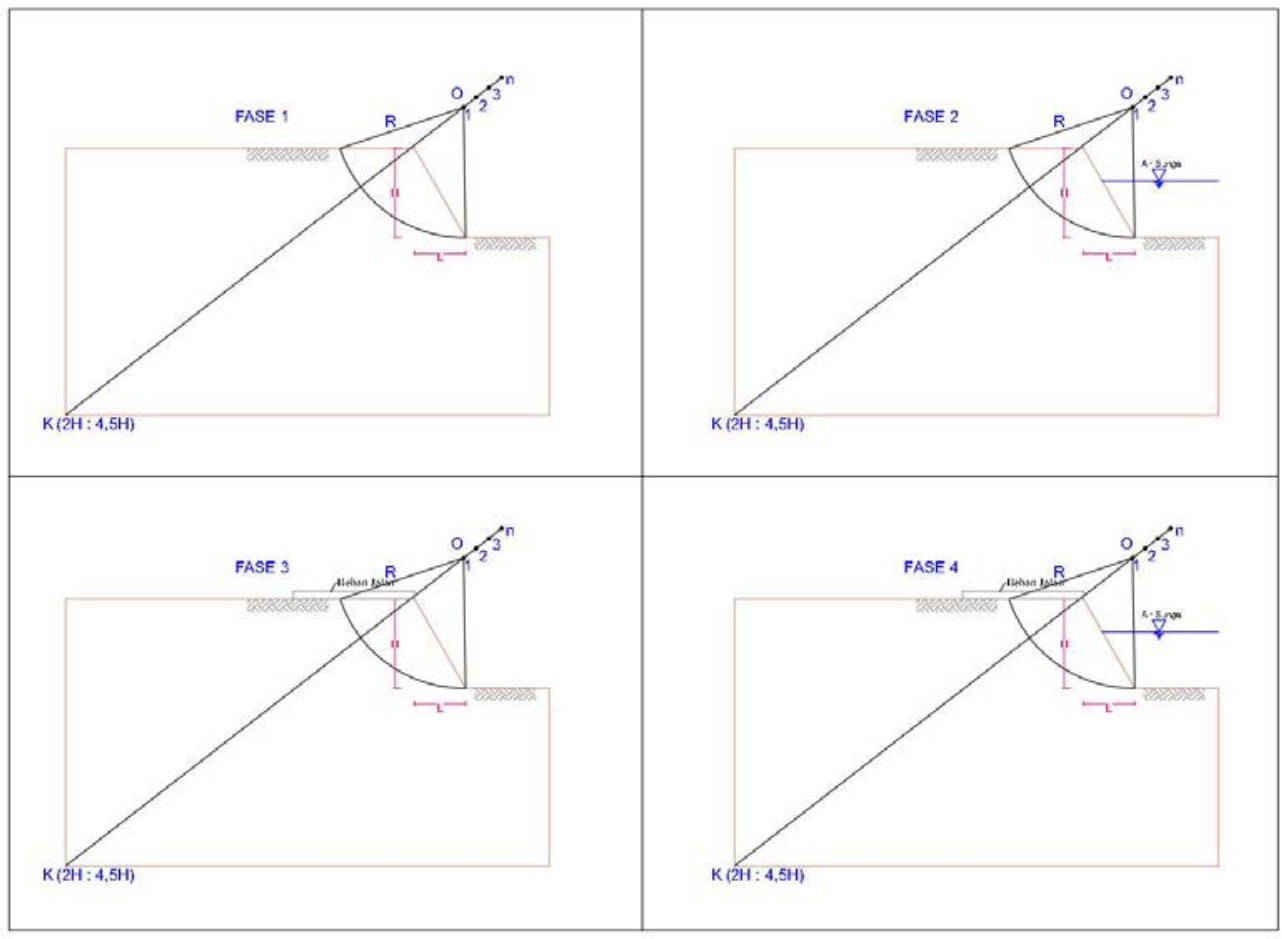

Gambar 2. Fase perhitungan yang digunakan dalam analisis perencanaan. Sumber: Data hasil olahan sendiri 
Analisis manual stabilitas lereng menggunakan metode irisan biasa (Fellenius), penentuan titik pusat longsor dilakukan dengan cara coba - coba (trial and error) dan dengan bantuan sudutsudut petunjuk Fellenius. Dengan pendekatan pula diperoleh koordinat titik $\mathrm{K} \quad(2 \mathrm{H} \quad$ : 4,5H) yang kemudian dihubungkan dengan titik pusat longsor yang merupakan letak titik pusat busur longsor. Sedangkan analisis program PLAXIS versi 8.2 dilakukan dengan menggunakan metode elemen hingga.
Metode elemen hingga yang digunakan adalah dalam kondisi regangan bidang (plane strain). Model plane strain digunakan dengan asumsi bahwa sepanjang sumbu potongan melintang lereng relatif sama dan peralihan dalam arah tegak lurus potongan tersebut dianggap tidak terjadi. Dari 2 metode analisis tersebut maka diperoleh tabel hasil perbandingan faktor keamanan antara metode Fellenius dan program PLAXIS versi 8.2 sebagai berikut

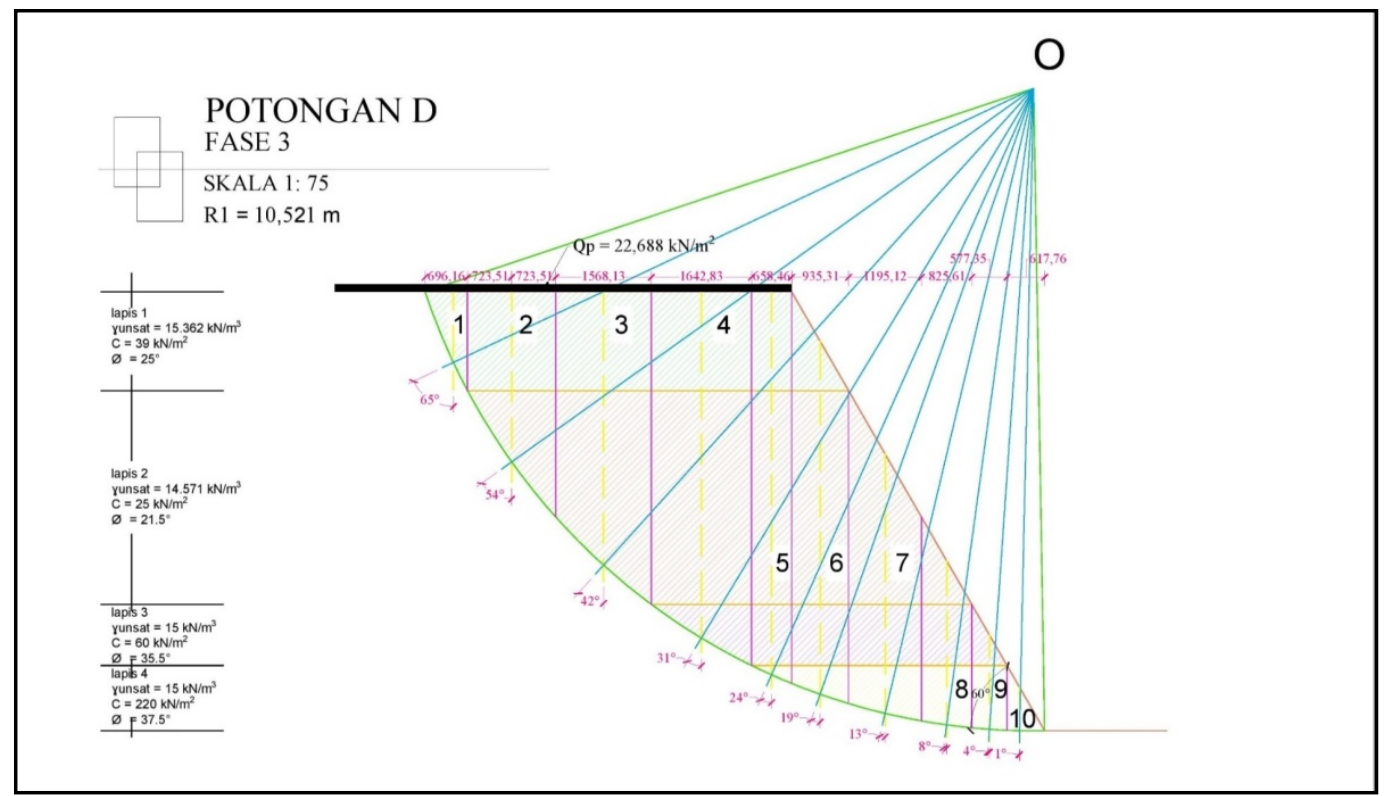

Gambar 3. Potongan D fase 3

Sumber: Data hasil olahan sendiri

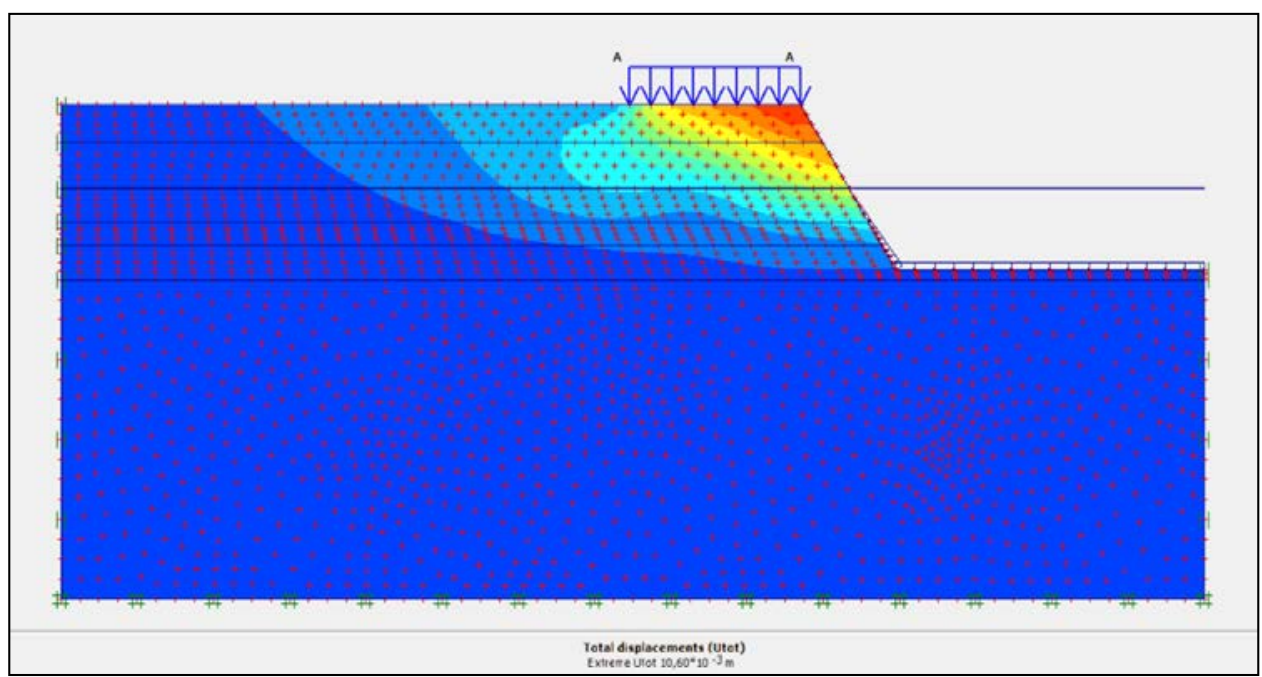

Gambar.4 Lereng pada potongan D yang terdeformasi akibat berat sendiri tanah, beban jalan, dan muka air banjir.

Sumber: Data hasil olahan sendiri 
Tabel.3 Analisis faktor keamanan dengan Metode Fellenius dan menggunakan Program PLAXIS versi 8.2

\begin{tabular}{|c|c|c|c|c|c|c|}
\hline \multirow{2}{*}{ Potongan } & \multirow{2}{*}{ Fase } & \multirow{2}{*}{ Kondisi } & \multirow{2}{*}{$\begin{array}{l}\text { Metode Fellenius } \\
\text { Faktor Keamanan }\end{array}$} & Program Plaxis V.8.2 & \multirow{2}{*}{ Syarat } & \multirow{2}{*}{$\begin{array}{c}\text { Keteranga } \\
n\end{array}$} \\
\hline & & & & Faktor Keamanan & & \\
\hline \multirow[t]{4}{*}{ A } & 1 & Berat sendiri tanah & 3,873 & $1,268 \mathrm{E}+29$ & \multirow{20}{*}{$\begin{array}{c}\mathrm{FK}>1.25 \text { Aman } \\
\mathrm{FK}<1.25 \text { Tidak } \\
\quad \text { aman }\end{array}$} & Aman \\
\hline & 2 & Berat sendiri tanah dan muka air banjir & 14,815 & $1,268 \mathrm{E}+29$ & & Aman \\
\hline & 3 & Berat sendiri tanah dan beban jalan & 1,306 & 3,984 & & Aman \\
\hline & 4 & $\begin{array}{l}\text { Berat sendiri tanah, beban luar, dan } \\
\text { muka air banjir }\end{array}$ & 1,540 & 3,888 & & Aman \\
\hline \multirow[t]{4}{*}{ B } & 1 & Berat sendiri tanah & 2,294 & $1,268 \mathrm{E}+29$ & & Aman \\
\hline & 2 & Berat sendiri tanah dan muka air banjir & 4,348 & $1,268 \mathrm{E}+29$ & & Aman \\
\hline & 3 & Berat sendiri tanah dan beban jalan & 1,461 & 4,301 & & Aman \\
\hline & 4 & $\begin{array}{c}\text { Berat sendiri tanah, beban luar, dan } \\
\text { muka air banjir }\end{array}$ & 2,099 & 4,301 & & Aman \\
\hline \multirow[t]{4}{*}{$\mathrm{C}$} & 1 & Berat sendiri tanah & 3,647 & $1,268 \mathrm{E}+29$ & & Aman \\
\hline & 2 & Berat sendiri tanah dan muka air banjir & 7,471 & $1,268 \mathrm{E}+29$ & & Aman \\
\hline & 3 & Berat sendiri tanah dan beban jalan & 1,462 & 4,251 & & Aman \\
\hline & 4 & $\begin{array}{c}\text { Berat sendiri tanah, beban luar, dan } \\
\text { muka air banjir }\end{array}$ & 1,911 & 4,251 & & Aman \\
\hline \multirow[t]{4}{*}{$\mathrm{D}$} & 1 & Berat sendiri tanah & 6,032 & $1,268 \mathrm{E}+29$ & & Aman \\
\hline & 2 & Berat sendiri tanah dan muka air banjir & 14,716 & $1,268 \mathrm{E}+29$ & & Aman \\
\hline & 3 & Berat sendiri tanah dan beban jalan & 1,287 & 4,296 & & Aman \\
\hline & 4 & $\begin{array}{c}\text { Berat sendiri tanah, beban luar, dan } \\
\text { muka air banjir }\end{array}$ & 1,771 & 3,718 & & Aman \\
\hline \multirow[t]{4}{*}{$\mathrm{E}$} & 1 & Berat sendiri tanah & 3,612 & $1,268 \mathrm{E}+29$ & & Aman \\
\hline & 2 & Berat sendiri tanah dan muka air banjir & 8,717 & $1,268 \mathrm{E}+29$ & & Aman \\
\hline & 3 & Berat sendiri tanah dan beban jalan & 1,560 & 3,972 & & Aman \\
\hline & 4 & $\begin{array}{c}\text { Berat sendiri tanah, beban luar, dan } \\
\text { muka air banjir }\end{array}$ & 1,951 & 3,924 & & Aman \\
\hline
\end{tabular}

Tabel.4 Analisis deformasi di lereng dengan Program Plaxis versi 8.2

\begin{tabular}{|c|c|c|c|}
\hline Potongan & Fase & Kondisi & Deformasi V.8.2 (cm) \\
\hline \multirow[t]{4}{*}{ A } & 1 & Berat sendiri tanah & 0 \\
\hline & 2 & Berat sendiri tanah dan muka air banjir & 0 \\
\hline & 3 & Berat sendiri tanah dan beban jalan & 1,532 \\
\hline & 4 & Berat sendiri tanah, beban luar, dan muka air banjir & 1,532 \\
\hline \multirow[t]{4}{*}{ B } & 1 & Berat sendiri tanah & 0 \\
\hline & 2 & Berat sendiri tanah dan muka air banjir & 0 \\
\hline & 3 & Berat sendiri tanah dan beban jalan & 2,142 \\
\hline & 4 & Berat sendiri tanah, beban luar, dan muka air banjir & 2,142 \\
\hline \multirow[t]{4}{*}{$\mathrm{C}$} & 1 & Berat sendiri tanah & 0 \\
\hline & 2 & Berat sendiri tanah dan muka air banjir & 0 \\
\hline & 3 & Berat sendiri tanah dan beban jalan & 2,07 \\
\hline & 4 & Berat sendiri tanah, beban luar, dan muka air banjir & 2,07 \\
\hline \multirow[t]{4}{*}{$\mathrm{D}$} & 1 & Berat sendiri tanah & 0 \\
\hline & 2 & Berat sendiri tanah dan muka air banjir & 0 \\
\hline & 3 & Berat sendiri tanah dan beban jalan & 2,12 \\
\hline & 4 & Berat sendiri tanah, beban luar, dan muka air banjir & 2,12 \\
\hline \multirow[t]{4}{*}{$\mathrm{E}$} & 1 & Berat sendiri tanah & 0 \\
\hline & 2 & Berat sendiri tanah dan muka air banjir & 0 \\
\hline & 3 & Berat sendiri tanah dan beban jalan & 1,823 \\
\hline & 4 & Berat sendiri tanah, beban luar, dan muka air banjir & 1,823 \\
\hline
\end{tabular}




\section{KESIMPULAN}

Kesimpulan yang dapat diambil dari hasil Perencanaan Lereng Sungai Sugutamu Pada Lokasi Proyek Pesona Square Depok yaitu dari hasil perencanaan didapat bentuk dan sudut kemiringan lereng Sungai Sugutamu yang berada di sekitar proyek pembangunan Pesona Square Depok yaitu $60^{\circ}$ dan tanpa undak (nostaging). Dengan bentuk dan kemiringan tersebut, proyek Pesona Square Depok tidak perlu menggeser rencana jalan yang telah direncanakan sebelumnya.

Angka keamanan terkecil yang diperoleh berdasarkan Metode Fellenius sebesar 1,287 yang terdapat pada fase ke-3 potongan D. Sedangkan, angka keamanan terkecil yang diperoleh dari hasil program PLAXIS versi 8.2 yaitu 3,718 yang terdapat pada fase ke-4 potongan D. Semua angka keamanan yang didapat dari hasil analisis lebih besar dari syarat keamanan $(>1,25)$. Namun, angka keamanan tersebut mempunyai selisih yang cukup jauh. Hal tersebut dapat disebabkan oleh; 1) Penentuan titik pusat bidang longsor yang tidak sama antara perhitungan manual dengan perhitungan dengan PLAXIS versi 8.2 ; 2) Muka air banjir pada program PLAXIS versi 8.2 tidak dianggap sebagai penggerak maupun penahan, sedangkan pada perhitungan manual, muka air banjir dianggap sebagai penahan karena analisis ditinjau secara 2 dimensi sehingga arah tidak diperhitungkan dan hanya berat air yang bekerja pada perhitungan.

\section{DAFTAR PUSTAKA}

[1] Alkausar, Edo \& Shesia, Vinasha. 2016. "Analisis Stabilitas Lereng Di Perumahan Taman Sriwijaya Akibat Aktivitas Pembangunan Hotel Ayola. Depok: Jurusan Teknik Sipil Politeknik Negeri Jakarta.

[2] Ariyandi, Sony \& Zakki, Muhammad. 2008. Perencanaan Perkuatan Pondasi Jembatan Cable
Stayed Menado. Bandung: Jurusan Teknik Sipil Institut Teknologi Bandung.

[3] Bangunan, Direktorat P.M. 1983. Peraturan Pembebanan Indonesia Untuk Gedung 1983. Jakarta: Stensil.

[4] Bowles, J.E. 1992. Analisis dan Desain Pondasi, Jilid I Edisi keempat. Jakarta: Erlangga.

[5] Bowles, J.E. 1992. Analisis dan Desain Pondasi, Jilid II Edisi keempat. Jakarta: Erlangga.

[6] BSN. 2016. SNI 1725-2016 Pembebanan untuk Jembatan. Jakarta: Badan Standarisasi Nasional.

[7] Chahyono, Bayu. 2012. Analisis Stabilitas Lereng Tanah Lempung Jenuh Dengan Metode Probabilitas. Surakarta: Fakultas Teknik Sipil Universitas Muhammadiyah Surakarta. [diunduh 25 Mei 2017)]. URL

http://eprints.ums.ac.id/18359/.

[8] Das, B.M., Endah, Noor \& Mochtar, Indrasurya B. $1995 . \quad$ Mekanika Tanah (Prinsip-prinsip Rekayasa Geoteknis), Jilid 1. Jakarta: Erlangga.

[9] Das, B.M., Endah, Noor \& Mochtar, Indrasurya B. 1995. Mekanika Tanah (Prinsip-prinsip Rekayasa Geoteknis), Jilid 2. Jakarta: Erlangga.

[10] Grim, R.E.. 1953. Clay Mineralogy: McGraw-Hill Book Co., Inc.

[11] Hardyatmo, H.C. 2010. Mekanika Tanah 1, Edisi ke-lima. Yogyakarta: Gajah Mada University Press.

[12] Hardyatmo, H.C. 2010. Mekanika Tanah 2, Edisi ke-lima. Yogyakarta: Gajah Mada University Press.

[13] Wikipedia. 2016. [diunduh 15 April 2017]. URL https://id.wikipedia.org/wiki/Kota_ Depok/

[14] Pratikso. 2008. Mekanika Tanah I. Semarang: Fakultas Teknik Sipil Universitas Islam Sultan Agung. 
[15] PT. Solefound Sakti. 2015. Laporan Hasil Penyelidikan Tanah Proyek Pembangunan Pesona Square Depok. Jakarta: PT. Solefound Sakti.

[16] Puskim Kementerian Pekerjaan Umum. 2010. Peta Zonasi Gempa Indonesia. [diunduh 17 Juni 2017]. URL

http://puskim.pu.go.id/Aplikasi/desa in_spektra_indonesia_2011/.

[17] PVMBG. 2009. Peta Zona Kerentanan Tanah Kota Depok. [diunduh 17 Juni 2017. URL http://vsi.esdm.go.id/gallery/picture. php?/104/category/15

[18] Robertson. 2010. Soil Behaviour Type From The CPT. California: Geotechnical Journal.

[19] Schaetzl, Randall \& Anderson, Sharon. 2005, Soils, First Edition. New York: Cambridge University Press.

[20] Syaeful. 2012. Potensi \& Bentuk Bidang Runtuhan Pada Lereng Tambang Terbuka. Jakarta: Jurnal Pusat Pengembangan Geologi Nuklir.

[21] Terzaghi, Karl, Peck, Ralph B. \& Mesri, Gholamreza. 1996, Soil Mechanics In Engineering Practice, Third Edition. Canada: John Wiley \& Sons Inc.

[22] Turkandi, T., Agustiyanto, D.A \& Hadiwidjoyo, M.M. Purbo. 1992. Peta Geologi Lembar Jakarta dan Kepulauan Seribu, Jawa. Bandung: Pusat Penelitian dan Pengembangan Geologi.

[23] Wibowo, D.A. \& Pratiwi, Endah. 2007. Analisa Stabilitas Lereng Dan Alternatif Penanganannya Studi Kasus Jalan Gombel Lama Semarang. Semarang: Fakultas Teknik Universitas Diponegoro. [diunduh 16 April 2017]. URL http://eprints.undip.ac.id/id/eprint/33 910/.
[24] Zakaria, Zufialdi. 2011. Diktat Kuliah Geoteknik Analisis Kestabilan Lereng Tanah. Bandung: Fakultas Teknik Geologi Universitas 
Putra Agung Maha Agung dkk, Perencanaan Lereng Sungai... 